\title{
True and Fair View of Financial Reporting Practices: Accountants' Perspective
}

\author{
Muhammad Akhtar ${ }^{1 *}$, Mubashar Hassan Zia ${ }^{2}$, Faisal Shehzad ${ }^{3}$ \\ ${ }^{1}$ Assistant Professor FAST School of Management, National University of Computer \& Emerging Sciences, \\ Islamabad, Pakistan \\ ${ }^{2}$ Sr. Lecturer, Faculty of Management Sciences, Riphah International University, Islamabad, Pakistan \\ ${ }^{3}$ Assistant Professor, COMSATS institute of Information Technology, Attock, Pakistan
}

\section{Keywords}

True and Fair View

Financial Reporting Practices

Accountant's Perspective

Financial Statements

Accounting Standards

\begin{abstract}
The purpose of this case article is to bridge the gap between theory and practice of financial reporting by analyzing the reporting practices from an accountant's perspective. True and fair financial reporting is the basic requirement for achieving the objectives if Islamic financial system. Importantly, what causes the accountants to mismark the financial status of the companies has been spotlighted. It depicts the impact of aggressive revenue recognition, outright fraud, failing to accrue liability, misclassification of operating and non operating income and expenses, understatement and capitalization of expenses on financial statements. The management manipulates financial statements to have good impression about its performance and to shoe profitability, better return on assets, return on equity and debt ratios.

Study provides evidence for the mechanics used for manipulation and provides valuable input for the motives for aggressive reporting and outright fraud. It highlights the importance of accounting model to help and trace the manipulated financial statements for efficient investment decisions. The results of the study cannot be generalized to all countries because of difference in the adoption of international accounting standards, international financial reporting standards, generally accepted accounting principles and AAOFI standards in some cases.
\end{abstract}

KAUJIE Classification: H54, L1, L33

JEL Classification: M41

(C) 2018 JIBM. All rights reserved.

\section{INTRODUCTION}

The contamination in financial statements has compelled the researchers to look into financial reporting issues which caused the collapse of even big firms like, Enron, World Com, One Tel, Barings Bank, etc. Contamination in financial statements has extended the use of

\footnotetext{
*Corresponding author: Muhammad Akhtar

${ }^{\dagger}$ Email: muhammad.akhtar@nu.edu.pk
} 
algorithm to detect the possibility of defaults in banks (De Marco, Donnini, Gioia, \& Perla, 2018). The manipulations in financial statements have forced the economists, mathematicians and analysts to develop the tools which could help to detect financial irregularities. The polytomous response logit models are the example of evaluating risk factors, which help the user of financial statements to detect financial failures (Tinoco, Holmes, \& Wilson, 2018). Therefore, the current study bridges the gap between theory and practice by analyzing the true and fair view of financial reporting practices from an accountant's perspective.

The financial statements are the major source of financial information. Investor makes decision on the bases of information provided in the financial statements and financial markets are more volatile with respect to financial information presented in financial statements (Akhtar, Naveed, \& Bilal, 2016). Even financially literate investors have exposure to risk while participating in the stock markets (Akhtar \& Muhammad, 2017). Therefore, complete reliance on financial statements may be misleading as they may contain manipulated information.

The ongoing debate on the framework of accounting and assumptions of accounting models have opened the doors for accountant's to use accounting assumptions in their own interest. Even the framework of accounting failed to resolve many prominent issues (Mala \& Chand, 2015). This is happening in the presence of leading accounting bodies like Financial Accounting Standard Board (FASB) and International Accounting Standard Board (IASB). These accounting bodies are helpless to control, monitor and cover the manipulations in financial statements. Lack of any well-defined accounting model and violation of its assumptions may lead to manipulated financial statements (Ahmed, Akhtar, Ahmed, \& Aziz, 2017).

Therefore the current study is an attempt to help the users of financial statements to know the specific accounting tactics normally played by the accountants. Further, study suggests that there is need to develop sound accounting conceptual framework which would be helpful for the formation of International Accounting Standards (IAS), International Financial Reporting Standards (IFRS) and AAOIFI Shari`‘ah standards.

\section{Motives behind Manipulations of the Income Statement}

Integrity of financial reports is at stake due to increasing practices of earnings management that continues to impact managers decision making (Hanif, 2010). Most importantly, actual earnings management is increasing as compare to accrual based earnings management, which depicts the aggressive attitude of management (Commerford, Hatfield, \& Houston, 2018). The major motive behind manipulation of financial statements could be the overstatement of revenues for the satisfaction of creditors and investors. Investors are interested in returns and creditors are interested in recovery of their receivables. Therefore, they are being facilitated by showing higher earnings. Second motive behind overstatement of earnings could be enticing outside investors and creditors. Thirdly, the motive behind understatement of incomes would be to avoid the taxes from taxes authorities, concealment of poor performance, and avoidance of negative earnings (Hanif, 2010). Fourthly, fictitious increase or decrease in assets, liabilities and profitability improve the profitability ratios, return on 
assets, return on equity and debt ratios. Fifthly, manager's compensation linked with earnings motivates managers to play accounting games and to manipulate financial statements. Sixth, the management wants to create good impression and to look batter in the eyes of different stakeholders which motivates them to manipulate financial statements.

\section{Objectives of the Study}

Keeping in view the above, the major objective of the current study is to high light the importance of accounting model and to create awareness regarding the traditional assumptions of accounting model. Second objective is to provide evidence regarding the mechanics used for the violations of accounting model and how such violations can be traced. Thirdly, the study provides valuable input regarding the differentiation between aggressive reporting and outright fraud. Fourthly, the study highlights the motives behind the manipulation of financial statements. The study is to enable the readers of financial statements to identify and trace the tools and techniques which have been used in the manipulation of the financial statements. It is to enable the readers to identify the manipulated financial statement for effective and efficient investment decisions.

\section{Aggressive Reporting and Outright Fraud}

While manipulating financial statements, accountants may opt for aggressive reporting or outright fraud. Aggressive reporting refers to reporting revenues of future contracts which have not been executed yet, while outright fraud would be to record revenues even when there is no contract. For aggressive reporting and outright fraud company uses the following tactics such as:

- Overstatement of gross profits or the operating profits.

- Misclassification of lease contracts.

- Record sales when simply any contract is signed, or even the contract is not signed.

- Deferment of expenses.

- Misclassification of expenses.

- Misclassification of revenues and

- Misclassification of operating and non operating incomes and expenses.

The above mentioned techniques are normally used by management and accountants to manipulate financial statements. Let's have a discussion on the financial statements of Hassan traders (hypothetical entity) by taking hypothetical values. The main components of income statement are sales/revenues or expenses. The change in both accounts can change the performance of the business. Overstatement of revenues or understatement of expenses will increase net income. Understatement of revenues or overstatement of expenses will decrease income. 


\section{Manipulations in Sub-totals of Income Statement}

Some companies may overstate or understate the net income, and only overstate the revenues and some subtotals such as gross profit and operating profits, etc. Overstatement of sub-total improves the ratio analysis regarding gross profit and operating profit ratios. Firms are even engaged in upward manipulations having small profits or small losses (Makarem, Hussainey, $\&$ Zalata, 2018). Manipulation may not affect only one financial statement. Two or more than two financial statements could be effected by disturbing only one account in any financial statement. For example, if an accountant record prepaid rent expense instead of rent expense, it would improve net profit, and would also be recorded as an asset in the balance sheet. If the fraud has been committed by the firm intentionally, it is very difficult to be detected even for the expert auditor. However, high commitment to corporate social responsibility may reduce earnings management (Aribi \& Thankom, 2018). Therefore, the knowledge of the games normally played by accountants can facilitate to detect manipulated financial statements. The firms may be involved in multiple games at time. However, these are discussed separately-possible manipulations in income statement and then manipulations in balance sheet.

TABLE 1

Ali Hassan Traders Income Statement 30, 2017

\begin{tabular}{lll}
\hline \hline & Original & Forged \\
\hline Sales & 200,000 & 300,000 \\
Less cost of goods sold & $(130,000)$ & \\
Gross Profit & 70,000 & \\
Electricity expense & $(10,000)$ & \\
Rent expense & $(10,000)$ & \\
Profit before interest and tax & 50,000 & \\
Less interest & $(5,000)$ & \\
Profit after interest before tax & 45,000 & \\
Less Tax & $(10,000)$ & \\
Profit after interest and tax /net profit & 35,000 & \\
\hline
\end{tabular}

Note: the amount of cost of goods sold, expenses, tax and interest have not been changed to simplify the calculation.

TABLE 2

Ali Hassan Traders Income Statement June 30, 2017

\begin{tabular}{|c|c|c|c|}
\hline Liabilities & Original Forged & Assets & Original Forged \\
\hline Notes and payables & 100,000 & Cash /bank & 50,000 \\
\hline Long term debt & 100,000 & Account receivables & 100,000 \\
\hline Common stock & 100,000 & Inventories & 50,000 \\
\hline Retained earnings & 100,000 & Plant and equipment & 200,000 \\
\hline Total Liabilities and Equity & 400,000 & Total Assets & 400,000 \\
\hline
\end{tabular}


1. Aggressive Revenue Recognition: showing record sales, showing record sales when only the sale contract of Rs. 100,000 is signed. This will increase profit after interest and tax in the income statement and account receivables and retained earnings in the balance sheet. This will also improve the results of ratio analysis.

2. Outright Fraud: Showing record sales even when contract is not signed for future sales of Rs. 200,000. This will also increase profit after interest and tax in the income statement and account receivables and retained earnings in the balance sheet. This, of course, will improve the results of ratio analysis.

TABLE 3

Ali Hassan Traders Income Statement June 30, 2017

\begin{tabular}{lll}
\hline \hline & Original & Forged \\
\hline Sales & 200,000 & 400,000 \\
Less cost of goods sold & $(130,000)$ & \\
Gross profit & 70,000 & \\
Electricity expense & $(10,000)$ & \\
Rent expense & $(10,000)$ & \\
Profit before interest and tax & 50,000 & \\
Less interest & $(5,000)$ & \\
Profit after interest before tax & 45,000 & \\
Less Tax & $(10,000)$ & \\
Profit after interest and tax /net profit & 35,000 & \\
\hline
\end{tabular}

Note: the amount of cost of goods sold, expenses, tax and interest have not been changed to simplify the calculation.

TABLE 4

Ali Hassan Traders Income Statement June 30, 2017

\begin{tabular}{|c|c|c|c|}
\hline Liabilities & Original Forged & Assets & Original Forged \\
\hline Notes and payables & 100,000 & Cash /bank & 50,000 \\
\hline Long term debt & 100,000 & Account receivables & 100,000 \\
\hline Common stock & 100,000 & Inventories & 50,000 \\
\hline Retained earnings & 100,000 & Plant and equipment & 200,000 \\
\hline Total Liabilities and Equity & 400,000 & Total Assets & 400,000 \\
\hline
\end{tabular}

3. Aggressive Revenue Recognition through Investments as Bank Deposits: By showing, for example, record sales when a contract of Rs. 150,000 is signed for future sales and creating an account of investments in bank deposits, instead of showing in account receivables. It could be done, because sharp increase in account receivables would be easily traceable by the auditor. To avoid this, normally a new account is created with the name of investment in bank deposits. It would increase the profit after interest and the tax; aslo improving the assets and liability side of the balance sheet. 
TABLE 5

Ali Hassan Traders Income Statement June 30, 2017

\begin{tabular}{lll}
\hline \hline Original & Forged & \\
\hline Sales & 200,000 & 350,000 \\
Less cost of goods sold & $(130,000)$ \\
Gross profit & 70,000 \\
Electricity expense & $(10,000)$ \\
Rent expense & $(10,000)$ \\
Profit before interest and tax & 50,000 \\
Less interest & $(5,000)$ \\
Profit after interest before tax & 45,000 \\
Less tax & $(10,000)$ \\
Profit after interest and tax /net profit & 35,000 \\
\hline
\end{tabular}

Note: the amount of cost of goods sold, expenses, tax and interest have not been changed to simplify the calculation.

TABLE 6

Ali Hassan Traders Income Statement June 30, 2017

\begin{tabular}{|c|c|c|c|}
\hline Liabilities & Original Forged & Assets & Original Forged \\
\hline Notes and payables & 100,000 & Cash /bank & 50,000 \\
\hline \multirow[t]{2}{*}{ Long term debt } & 100,000 & Account receivables & 100,000 \\
\hline & & Invest. in bank deposits & 0 \\
\hline Common stock & 100,000 & Inventories & 50,000 \\
\hline Retained earnings & 100,000 & Plant and equipment & 200,000 \\
\hline Total Liabilities and Equity & 400,000 & Total Assets & 400,000 \\
\hline
\end{tabular}

TABLE 7

Ali Hassan Traders Income Statement June 30, 2017

\begin{tabular}{lll}
\hline \hline & Original & Forged \\
\hline Sales & 200,000 & 200,000 \\
Less cost of goods sold & $(130,000)$ & $(100,000)$ \\
Gross profit & 70,000 & \\
Less expense & & \\
Electricity expense & $(10,000)$ & \\
Rent expense & $(10,000)$ & \\
Profit before interest and tax & 50,000 & \\
Less interest & $(5,000)$ & \\
Profit after interest before tax & 45,000 & \\
Less Tax & $(10,000)$ & \\
Profit after interest and tax /net profit & 35,000 & \\
\hline
\end{tabular}

Note: the amount of cost of goods sold, expenses, tax and interest has not been changed to simplify the calculation. 
TABLE 8

Cost of goods sold statement 30 June, 2017

\begin{tabular}{lll}
\hline \hline & Original & Forged \\
\hline Opening stock & 30,000 & \\
Add purchases & 150,000 & \\
Total available for sale & 180,000 & \\
Less closing stock & $(50,000)$ & $(80,000)$ \\
Cost of goods sold & 130,000 & \\
\hline
\end{tabular}

Note: the amount of cost of goods sold, expenses, tax and interest has not been changed to simplify the calculation.

TABLE 9

Ali Hassan Traders Balance Sheet As at June 30, 2017

\begin{tabular}{|c|c|c|c|}
\hline Liabilities & Original Forged & Assets & Original Forged \\
\hline Notes and payables & 100,000 & Cash /bank & 50,000 \\
\hline Long term debt & 100,000 & Account receivables & 100,000 \\
\hline Common stock & 100,000 & Inventories & 50,000 \\
\hline Retained earnings & 100,000 & Plant and equipment & 200,000 \\
\hline Total Liabilities and Equity & 400,000 & Total Assets & 400,000 \\
\hline
\end{tabular}

TABLE 10

Ali Hassan Traders Income Statement June 30, 2017

\begin{tabular}{lll}
\hline \hline & Original & Forged \\
\hline Sales & 200,000 & \\
Less cost of goods sold & $(130,000)$ & \\
Gross profit & 70,000 & \\
Less expense & & \\
Electricity expense & $(10,000)$ & \\
Rent expense & $(10,000)$ & $(0)$ \\
Profit before interest and tax & 50,000 & \\
Less interest & $(5,000)$ & \\
Profit after interest before tax & 45,000 & \\
Less tax & $(10,000)$ & \\
Profit after interest and tax /net profit & 35,000 & \\
\hline
\end{tabular}

Note: the amount of cost of goods sold, expenses, tax and interest has not been changed to simplify the calculation.

4. Understatement of Expenses through Manipulation in Cost of Goods Sold Statement. For example, accountant does not transfer the cost of inventory to the cost of goods sold. In this situation earnings after interest and tax will increase along with the increase in retained 
earnings and assets in the balance sheet. The accountant may also increase the amount of closing stock which would reduce the cost of goods sold. In case of physical verification of the inventory by the auditor, the physical inventory could be reconciled with the recorded inventory by borrowing the inventory from suppliers.

TABLE 11

Ali Hassan Traders Balance Sheet As at June 30, 2017

\begin{tabular}{|c|c|c|c|}
\hline Liabilities & Original Forged & Assets & $\begin{array}{ll}\text { Original } & \text { Forged }\end{array}$ \\
\hline \multirow[t]{2}{*}{ Notes and payables } & 100,000 & Cash /bank & 50,000 \\
\hline & & Prepaid rent & 0 \\
\hline Long term debt & 100,000 & Account receivables & 100,000 \\
\hline Common stock & 100,000 & Inventories & 50,000 \\
\hline Retained earnings & 100,000 & Plant and equipment & 200,000 \\
\hline Total Liabilities and Equity & 400,000 & Total Assets & 400,000 \\
\hline
\end{tabular}

5. Understatement of Expenses through Capitalization of Expense: For example, recording rent expense of Rs. 10,000 as prepaid rent. In this situation, the earnings after interest and tax would increase along with the increase in retained earnings on the liability side of the balance sheet and prepaid rent as an asset on the asset side of the balance sheet. Normally such manipulations are not deductable. If they are traced by the auditor, the reason normally provided by the accountant's is that it was misclassification error and no bad intentions were involved; would be settled at the end of specific accounting period.

TABLE 12

Ali Hassan Traders Income Statement June 30, 2017

\begin{tabular}{lll}
\hline \hline & Original & Forged \\
\hline Sales & 200,000 & \\
Less cost of goods sold & $(130,000)$ & \\
Gross profit & 70,000 & \\
Less expense & & \\
Electricity expense & $(10,000)$ & $(0)$ \\
Rent expense & $(10,000)$ & \\
Profit before interest and tax & 50,000 & \\
Less interest & $(5,000)$ & \\
Profit after interest before tax & 45,000 & \\
Less Tax & $(10,000)$ & \\
Profit after interest and tax /net profit & 35,000 & \\
\hline
\end{tabular}

Note: the amounts of cost of goods sold, expenses, tax and interest have not been changed to simplify the calculation. 
TABLE 13

Ali Hassan Traders Balance Sheet As at June 30, 2017

\begin{tabular}{|c|c|c|c|c|}
\hline Liabilities & Original & Forged & Assets & Original $\quad$ Forged \\
\hline Notes and payables & 100,000 & & Cash /bank & 60,000 \\
\hline Electricity bill payable & 10,000 & 0 & & \\
\hline Long term debt & 100,000 & & Account receivables & 100,000 \\
\hline Common stock & 100,000 & & Inventories & 50,000 \\
\hline Retained earnings & 100,000 & & Plant and equipment & 200,000 \\
\hline Total Liabilities and Equity & 410,000 & & Total Assets & 410,000 \\
\hline
\end{tabular}

TABLE 14

Ali Hassan Traders Income Statement June 30, 2017

\begin{tabular}{lll}
\hline \hline & Original & Forged \\
\hline Sales & 200,000 & 250,000 \\
Less cost of goods sold & $(130,000)$ & \\
Gross profit & 70,000 & \\
Electricity expense & $(10,000)$ & \\
Rent expense & $(10,000)$ & \\
Add other income & 50,000 & 0 \\
Profit before interest and tax & 100,000 & \\
Less interest1 & $(5,000)$ & \\
Profit after interest before tax & 95,000 & \\
Less tax 1 & $(10,000)$ & \\
Profit after interest and tax /net profit & 85,000 & \\
\hline \hline
\end{tabular}

Note: the amount of cost of goods sold, expenses, tax and interest has not been changed to simplify the calculation.

TABLE 15

Ali Hassan Traders Balance Sheet As at June 30, 2017

\begin{tabular}{|c|c|c|c|}
\hline Liabilities & Original Forged & Assets & Original Forged \\
\hline Notes and payables & 100,000 & Cash /bank & 50,000 \\
\hline Long term debt & 100,000 & Account receivables & 100,000 \\
\hline Common stock & 100,000 & Inventories & 50,000 \\
\hline Retained earnings & 100,000 & Plant and equipment & 200,000 \\
\hline Total Liabilities and Equity & 400,000 & Total Assets & 400,000 \\
\hline
\end{tabular}

6. Understatement of Expenses through Failing to Accrue a Liability: For example, service received for electricity of Rs 10,000 is not yet paid. In this situation earnings after interest and tax would increase along with the increase in retained earnings on the liability side of the balance sheet, and reduction in electricity bill payable on the liability side of the balance sheet. Normally such manipulations are difficult to deduct. If the amount is traced by the 
auditor the reason normally provided by the accountant's is that it was error of omission, without any bad intention and that it would be settled at the end of specific accounting period. 7. Manipulation through Classification of Non-Operating Income as Revenues. In this situation, earnings after interest and tax would not increase and there would be no effect on retained earnings and assets on the balance sheet. Normally such manipulation is done to show the better performance of the business from the operations. In case such reporting is traced by the auditor, the reason normally provided by the accountants is that it was misinterpretation of the International Accounting Standard (IAS,1) i.e., Presentations of Financial Statements. No bad intention was involved as there was no change in the profit in the income statement and assets and liability side of the company's balance sheet. However the profitability ratios such as gross profit ratio, operating profit ratio, profit before interest and tax will present better picture of the performance of the company.

TABLE 16

Ali Hassan Traders Income Statement June 30, 2017

\begin{tabular}{lll}
\hline \hline & Original & Forged \\
\hline Sales & 200,000 & \\
Less cost of goods sold & $(130,000)$ & 100,000 \\
Gross profit & 70,000 & \\
Electricity expense & $(10,000)$ & \\
Rent expense & $(10,000)$ & \\
Less other expenses & 0 & $(30,000)$ \\
Profit before interest and tax & 50,000 & \\
Less interest1 & $(5,000)$ & \\
Profit after interest before tax & 45,000 & \\
Less tax1 & $(10,000)$ & \\
Profit after interest and tax /net profit & 35,000 & \\
\hline
\end{tabular}

Note: the amount of expenses, tax and interest has not been changed to simplify the calculation.

TABLE 17

Ali Hassan Traders Balance Sheet As at June 30, 2017

\begin{tabular}{|c|c|c|c|}
\hline Liabilities & Original Forged & Assets & Original Forged \\
\hline Notes and payables & 100,000 & Cash /bank & 50,000 \\
\hline Long term debt & 100,000 & Account receivables & 100,000 \\
\hline Common stock & 100,000 & Inventories & 50,000 \\
\hline Retained earnings & 100,000 & Plant and equipment & 200,000 \\
\hline Total Liabilities and Equity & 400,000 & Total Assets & 400,000 \\
\hline
\end{tabular}

8. Manipulation through Classification of Operating Expense as Non-Operating Expense: In this situation earnings after interest and tax will not increase and there will be no effect in retained earnings on the liability side of the balance sheet and no effect on the asset side of 
the balance sheet. Normally such manipulations are done to show the better performance of the business from the operations. The amount of cost of goods sold is reduced to increase gross profit and the same is presented as other expense in the income statement. If traced by the auditor the reason normally provided by the accountant's is that it was misinterpretation of the International Accounting Standard (IAS,1) i.e., Presentations of Financial Statements. No bad intention was involved as there is no change in the profit after interest and tax in the assets and liabilities of the company.

\section{Resolving the Issues indicated in the Study Traditional Assumptions of Accounting Models}

The traditional assumptions of accounting models are based on business entity concept, going concern or continuity, time period, monetary unit, historical cost, conservatism, realization, matching, consistency, full disclosure and materiality.

\section{Identification of the Violations of Accounting Model}

The main components of income statement are sales/revenues and expenses. The change in any of the both accounts can change the performance of the business. Overstatement of revenues or understatement of expenses would increase net income. Understatement of revenues or overstatement of expenses would decrease income. Complete reliance on financial statements may be misleading because of manipulated information. The techniques which are normally used to violate the assumptions of accounting model include overstatement of gross profits or overstatement of operating profits, misclassification of lease contracts, record sales when contract is signed or even record sales when contract is not signed, deferment of expenses, misclassification of expenses, misclassification of revenues and misclassification of operating and non operating incomes and expenses.

\section{Motives of Manipulations in Financial Statements}

There are many motives behind manipulation in financial statements. The major motive could be the overstatement of revenues for satisfaction of the creditors and investors. Investors are interested in returns while creditors are interested in recovery of their funds. Therefore, they are lured because of high earnings. Second motive behind overstatement of earnings would be enticing outside investors and creditors. Thirdly, understatement of incomes could be to avoid the taxes from taxes authorities, concealment of poor performance, and avoidance negative earnings (Hanif, 2010). Fourthly, fictitious increase or decrease in assets, liabilities and profitability improves the profitability ratios, return on assets and return on equity and debt ratios. Fifth, manager's compensation linked to earnings motivates managers to play accounting games and to manipulate financial statements. Lastly, the management wants to create good impression and to look batter in the eyes of different stakeholders which motivates them to manipulate financial statements.

\section{Identifying the Manipulated Financial Statements}

The firms may be involved in multiple games to manipulate financial statements at a time. 
Therefore, the knowledge of the games normally played by the accountants could facilitate to detect manipulated financial statements. Following features in financial statements could be useful for identifying manipulated financial statements:

Check the sharp increase in account receivables: To avoid detection of such manipulation, normally a new account is created with the name of investment in bank accounts. The accountant may increase the amount of closing stock which would reduce the cost of goods sold. Physical verification of the inventory and reconciliation with the record can be helpful to detect such manipulated financial statements. Check misclassification errors and ensure that no bad intentions are involved. Check thoroughly the error of omission and misclassifications; Note the sudden better performance of the business due to misinterpretation of the International Accounting Standards (IASs); Review the amount of cost of goods sold, increase in gross profit and change in other expenses in the income statement; and finally, try to trace the abrupt relationships among these accounts.

\section{CONCLUSION AND FINDINGS}

TABLE 18

Ali Hassan Traders Income Statement June 30, 2017

\begin{tabular}{lll}
\hline \hline & Original & Forged \\
\hline Sales & 200,000 & 300,000 \\
Less cost of goods sold & $(130,000)$ & $(130,000)$ \\
Gross Profit & 70,000 & 170,000 \\
Electricity Expense & $(10,000)$ & $(10,000)$ \\
Rent Expense & $(10,000)$ & $(10,000)$ \\
Profit before Interest and Tax & 50,000 & 150,000 \\
Less Interest & $(5,000)$ & $(5,000)$ \\
Profit after interest before tax & 45,000 & 145,000 \\
Less Tax & $(10,000)$ & $(10,000)$ \\
Profit after Interest and Tax /Net Profit & 35,000 & 135,000 \\
\hline \hline
\end{tabular}

Note: the amount of cost of goods sold, expenses, tax and interest has not been changed to simplify the calculation.

TABLE 19

Ali Hassan Traders Balance Sheet As at June 30, 2017

\begin{tabular}{llllll}
\hline \hline Liabilities & Original & Forged & Assets & Original & Forged \\
\hline Notes and payables & 100,000 & 100,000 & Cash /bank & 50,000 & 50,000 \\
Long term debt & 100,000 & 100,000 & Account receivables & 100,000 & 200,000 \\
Common stock & 100,000 & 100,000 & Inventories & 50,000 & 50,000 \\
Retained earnings & 100,000 & 200,000 & Plant and equipment & 200,000 & 200,000 \\
Total Liabilities and equity & 400,000 & 500,000 & Total Assets & 400,000 & 500,000 \\
\hline \hline
\end{tabular}


TABLE 20

Ali Hassan Traders Income Statement June 30, 2017

\begin{tabular}{lll}
\hline \hline & Original & Forged \\
\hline Sales & 200,000 & 400,000 \\
Less cost of goods sold & $(130,000)$ & $(130,000)$ \\
Gross Profit & 70,000 & 270,000 \\
Electricity Expense & $(10,000)$ & $(10,000)$ \\
Rent Expense & $(10,000)$ & $(10,000)$ \\
Profit before Financial cost and Tax & 50,000 & 250,000 \\
Less Financial cost & $(5,000)$ & $(5,000)$ \\
Profit after financial cost before tax & 45,000 & 245,000 \\
Less Tax & $(10,000)$ & $(10,000)$ \\
Profit after Financial cost and Tax /Net Profit & 35,000 & 235,000 \\
\hline
\end{tabular}

Note: the amount of cost of goods sold, expenses, tax and financial cost has not been changed to simplify the calculation.

TABLE 21

Ali Hassan Traders Balance Sheet As at June 30, 2017

\begin{tabular}{llllll}
\hline \hline Liabilities & Original & Forged & Assets & Original & Forged \\
\hline Notes and payables & 100,000 & 100,000 & Cash /bank & 50,000 & 50,000 \\
Long term debt & 100,000 & 100,000 & Account receivables & 100,000 & 200,000 \\
Common stock & 100,000 & 100,000 & Inventories & 50,000 & 50,000 \\
Retained earnings & 100,000 & 200,000 & Plant and equipment & 200,000 & 200,000 \\
Total Liabilities and equity & 400,000 & 500,000 & Total Assets & 400,000 & 500,000 \\
\hline \hline
\end{tabular}

TABLE 22

Ali Hassan Traders Income Statement June 30, 2017

\begin{tabular}{lll}
\hline \hline & Original & Forged \\
\hline Sales & 200,000 & 300,000 \\
Less cost of goods sold & $(130,000)$ & $(130,000)$ \\
Gross Profit & 70,000 & 170,000 \\
Electricity Expense & $(10,000)$ & $(10,000)$ \\
Rent Expense & $(10,000)$ & $(10,000)$ \\
Profit before Financial cost and Tax & 50,000 & 150,000 \\
Less Financial cost1 & $(5,000)$ & $(5,000)$ \\
Profit after financial cost before tax & 45,000 & 145,000 \\
Less Tax1 & $(10,000)$ & $(10,000)$ \\
Profit after Financial cost and Tax /Net Profit & 35,000 & 135,000 \\
\hline
\end{tabular}

Note: the amount of cost of goods sold, expenses, tax and financial cost has not been changed to simplify the calculation. 
1. Aggressive revenue recognition: For example, showing record sales when only the sale contract of Rs. 100,000 is signed. It would increase profit after financing cost and tax in the income statement and account receivables and retained earnings in the balance sheet. It would also improve the results of ratio analysis.

2. Outright Fraud: For example, record sales even when contract is not signed for future sales of Rs. 200,000. This will also increase profit after financial cost and tax in the income statement and account receivables and retained earnings in the balance sheet. This will also improve the results of ratio analysis.

3. Aggressive Revenue Recognition through investments in Bank Deposits: For example, recording sales when only the contract of Rs. 150,000 for future sales is signed and create an account of investments in bank deposits, instead of increasing account receivables. The sharp increase in account receivables would be easily traceable by the auditor; to avoid this, normally a new account is created with the name of investment in bank deposits. It would increase the profit after financial cost and tax and would improve the assets and liability side of the balance sheet.

TABLE 23

Ali Hassan Traders Balance Sheet As at June 30, 2017

\begin{tabular}{llllll}
\hline \hline Liabilities & Original & Forged & Assets & Original & Forged \\
\hline Notes and payables & 100,000 & 100,000 & Cash /bank & 50,000 & 50,000 \\
Long term debt & 100,000 & 100,000 & Account receivables & 100,000 & 200,000 \\
Common stock & 100,000 & 100,000 & Inventories & 50,000 & 50,000 \\
Retained earnings & 100,000 & 200,000 & Plant and equipment & 200,000 & 200,000 \\
Total Liabilities and equity & 400,000 & 500,000 & Total Assets & 400,000 & 500,000 \\
\hline \hline
\end{tabular}

TABLE 24

Ali Hassan Traders Income Statement June 30, 2017

\begin{tabular}{lll}
\hline \hline & Original & Forged \\
\hline Sales & 200,000 & 200,000 \\
Less cost of goods sold & $(130,000)$ & $(100,000)$ \\
Gross Profit & 70,000 & 100,000 \\
Less Expense & & \\
Electricity Expense & $(10,000)$ & $(10,000)$ \\
Rent Expense & $(10,000)$ & $(10,000)$ \\
Profit before Financial cost and Tax & 50,000 & 80,000 \\
Less Financial cost & $(5,000)$ & $(5,000)$ \\
Profit after financial cost before tax & 45,000 & 75,000 \\
Less Tax & $(10,000)$ & $(10,000)$ \\
Profit after Financial cost and Tax /Net Profit & 35,000 & 65,000 \\
\hline
\end{tabular}

Note: the amount of cost of goods sold, expenses, tax and financial cost has not been changed to simplify the calculation. 
TABLE 25

Ali Hassan Traders CGS As at June 30, 2017

\begin{tabular}{lll}
\hline \hline & Original & Forged \\
Opening Stock & 30,000 & 30,000 \\
Add Purchases & 150,000 & 150,000 \\
Total Available for sale & 180,000 & 180,000 \\
Less Closing Stock & $(50,000)$ & $(80,000)$ \\
Cost of Goods sold & 130,000 & 100,000 \\
\hline \hline
\end{tabular}

TABLE 26

Ali Hassan Traders Balance Sheet As at June 30, 2017

\begin{tabular}{llllll}
\hline \hline Liabilities & Original & Forged & Assets & Original & Forged \\
\hline Notes and payables & 100,000 & 100,000 & Cash /bank & 50,000 & 50,000 \\
Long term debt & 100,000 & 100,000 & Account receivables & 100,000 & 100,000 \\
Common stock & 100,000 & 100,000 & Inventories & 50,000 & 80,000 \\
Retained earnings & 100,000 & 130,000 & Plant and equipment & 200,000 & 200,000 \\
Total Liabilities and equity & 400,000 & 430,000 & Total Assets & 400,000 & 430,000 \\
\hline \hline
\end{tabular}

TABLE 27

Ali Hassan Traders Income Statement June 30, 2017

\begin{tabular}{lll}
\hline \hline & Original & Forged \\
\hline Sales & 200,000 & 200,000 \\
Less cost of goods sold & $(130,000)$ & $(130,000)$ \\
Gross Profit & 70,000 & 70,000 \\
Less Expense & & \\
Electricity Expense & $(10,000)$ & $(10,000)$ \\
Rent Expense & $(10,000)$ & $(0)$ \\
Profit before Financial cost and Tax & 50,000 & 60,000 \\
Less Financial cost & $(5,000)$ & $(5,000)$ \\
Profit after financial cost before tax & 45,000 & 55,000 \\
Less Tax & $(10,000)$ & $(10,000)$ \\
Profit after Financial cost and Tax /Net Profit & 35,000 & 45,000 \\
\hline
\end{tabular}

Note: the amount of cost of goods sold, expenses, tax and financial cost has not been changed to simplify the calculation.

4. Understatement of Expenses through Manipulation in Cost of Goods Sold Statement: For example, the accountant fails to transfer cost of inventory to cost of goods sold. In this situation, earnings after financial cost and tax will increase along with the increase in retained earnings and assets in the balance sheet. The accountant may increase the amount of closing stock, which would reduce the cost of goods sold. In case of physical verification of the 
inventory by the auditor, the inventory would be reconciled with the recorded inventory by borrowing the inventory from suppliers.

TABLE 28

Ali Hassan Traders Balance Sheet As at June 30, 2017

\begin{tabular}{lcclll}
\hline \hline Liabilities & Original & Forged & Assets & Original & Forged \\
\hline Notes and payables & 100,000 & 100,000 & Cash /bank & 50,000 & 50,000 \\
& & & Prepaid Rent & 0 & 10,000 \\
Long term debt & 100,000 & 100,000 & Account receivables & 100,000 & 100,000 \\
Common stock & 100,000 & 100,000 & Inventories & 50,000 & 50,000 \\
Retained earnings & 100,000 & 110,000 & Plant and equipment & 200,000 & 200,000 \\
Total Liabilities and equity & 400,000 & 410,000 & Total Assets & 400,000 & 410,000 \\
\hline \hline
\end{tabular}

TABLE 29

Ali Hassan Traders Income Statement June 30, 2017

\begin{tabular}{lll}
\hline \hline & Original & Forged \\
\hline Sales & 200,000 & 200,000 \\
Less cost of goods sold & $(130,000)$ & $(130,000)$ \\
Gross Profit & 70,000 & 70,000 \\
Less Expense & & \\
Electricity Expense & $(10,000)$ & $(0)$ \\
Rent Expense & $(10,000)$ & $(10,000)$ \\
Profit before Financial cost and Tax & 50,000 & 60,000 \\
Less Financial cost & $(5,000)$ & $(5,000)$ \\
Profit after financial cost before tax & 45,000 & 55,000 \\
Less Tax & $(10,000)$ & $(10,000)$ \\
Profit after Financial cost and Tax /Net Profit & 35,000 & 45,000 \\
\hline
\end{tabular}

Note: the amount of cost of goods sold, expenses, tax and financial cost has not been changed to simplify the calculation.

TABLE 30

Ali Hassan Traders Balance Sheet As at June 30, 2017

\begin{tabular}{llllll}
\hline \hline Liabilities & Original & Forged & Assets & Original & Forged \\
\hline Notes and payables & 100,000 & 100,000 & Cash /bank & 60,000 & 60,000 \\
Electricity bill payable & 10,000 & 0 & & & \\
Long term debt & 100,000 & 100,000 & Account receivables & 100,000 & 100,000 \\
Common stock & 100,000 & 100,000 & Inventories & 50,000 & 50,000 \\
Retained earnings & 100,000 & 110,000 & Plant and equipment & 200,000 & 200,000 \\
Total Liabilities and equity & 410,000 & 410,000 & Total Assets & 410,000 & 410,000 \\
\hline \hline
\end{tabular}


5. Understatement of Expenses through Capitalization of Expense: For example, recording rent expense of Rs. 10,000 as prepaid rent. In this situation earnings after financial cost and tax will increase along with the increase in retained earnings on the liability side of the balance sheet and the prepaid rent on the asset side of the balance sheet. Normally, such manipulations are not deductable. If they are traced by the auditor, the reason normally provided by the accountants is that it was misclassification error and no bad intention was involved, it would be settled at the end of the accounting period.

6. Understatement of Expenses through Failing to Accrue a Liability: For example, service received for electricity of Rs 10,000 is not yet paid. In this situation, earnings after financial cost and tax will increase along with the increase in retained earnings on the liability side of the balance sheet, and reduction in electricity bill payable on the liability side of the balance sheet. If traced by the auditor, the reason normally provided by the accountants is that it was error of omission and no bad intention was involved and that it would be settled at the end of the accounting period.

7. Manipulations through Classification of Non-Operating Income as Revenues. In this situation earnings after financial cost and tax will not increase and there will be no effect on retained earnings and assets on the balance sheet. Normally such manipulations are done to show the better performance of the business from the operation. If they are traced by the auditor, the reason normally provided by the accountants is that it was misinterpretation of the International Accounting Standard (IAS-1) i.e., Presentations of Financial Statements. No bad intention was involved as there was no change in the profit after financial cost, and tax in the income statement and in assets and liability side of the company's balance sheet. However the profitability ratios such as gross profit ratio, operating profit ratio, profit before financial cost and tax will present better picture of the performance of the company.

TABLE 31

Ali Hassan Traders Income Statement June 30, 2017

\begin{tabular}{lll}
\hline \hline & Original & Forged \\
\hline Sales & 200,000 & 250,000 \\
Less cost of goods sold & $(130,000)$ & $(130,000)$ \\
Gross Profit & 70,000 & 120,000 \\
Electricity Expense & $(10,000)$ & $(10,000)$ \\
Rent Expense & $(10,000)$ & $(10,000)$ \\
Add other income & 50,000 & 0 \\
Profit before Financial cost and Tax & 100,000 & 100,000 \\
Less Financial cost1 & $(5,000)$ & $(5,000)$ \\
Profit after financial cost before tax & 95,000 & 95,000 \\
Less Tax1 & $(10,000)$ & $(10,000)$ \\
Profit after Financial cost and Tax /Net Profit & 85,000 & 85,000 \\
\hline \hline
\end{tabular}

Note: the amount of cost of goods sold, expenses, tax and financial cost has not been changed to simplify the calculation. 
TABLE 32

Ali Hassan Traders Balance Sheet As at June 30, 2017

\begin{tabular}{llllll}
\hline \hline Liabilities & Original & Forged & Assets & Original & Forged \\
\hline Notes and payables & 100,000 & 100,000 & Cash /bank & 50,000 & 50,000 \\
Long term debt & 100,000 & 100,000 & Account receivables & 100,000 & 100,000 \\
Common stock & 100,000 & 100,000 & Inventories & 50,000 & 50,000 \\
Retained earnings & 100,000 & 100,000 & Plant and equipment & 200,000 & 200,000 \\
Total Liabilities and equity & 400,000 & 400,000 & Total Assets & 400,000 & 400,000 \\
\hline \hline
\end{tabular}

8. Manipulations through Classification of Expense as Non-Operating Expense: In this situation earnings after financial cost and tax would not increase and there will be no effect in retained earnings on the liability side of the balance sheet and on assets side of the balance sheet. Normally, such manipulations are done to show the better business operations performance. The amount of cost of goods sold is reduced to increase gross profit and the same is presented as other expense in the income statement. In case traced by the auditor, the reason normally provided by the accountants is that it was misinterpretation of the International Accounting Standard (IAS,1) i.e., Presentations of Financial Statements. No bad intention was involved as there is no change in the profit after financial cost and tax and in the assets and liability side of the company's balance sheet.

TABLE 33

Ali Hassan Traders Income Statement June 30, 2017

\begin{tabular}{lll}
\hline \hline & Original & Forged \\
\hline Sales & 200,000 & 200,000 \\
Less cost of goods sold & $(130,000)$ & 100,000 \\
Gross Profit & 70,000 & 100,000 \\
Electricity Expense & $(10,000)$ & $(10,000)$ \\
Rent Expense & $(10,000)$ & $(10,000)$ \\
Less other expenses & 0 & $(30,000)$ \\
Profit before Financial cost and Tax & 50,000 & 50,000 \\
Less Financial cost & $(5,000)$ & $(5,000)$ \\
Profit after financial cost before tax & 45,000 & 45,000 \\
Less Tax & $(10,000)$ & $(10,000)$ \\
Profit after Financial cost and Tax /Net Profit & 35,000 & 35,000
\end{tabular}

Note: the amount of cost of goods sold, expenses, tax and financial cost has not been changed to simplify the calculation.

TABLE 34

Ali Hassan Traders Balance Sheet As at June 30, 2017

\begin{tabular}{llllll}
\hline \hline Liabilities & Original & Forged & Assets & Original & Forged \\
\hline Notes and payables & 100,000 & 100,000 & Cash /bank & 50,000 & 50,000 \\
Long term debt & 100,000 & 100,000 & Account receivables & 100,000 & 100,000 \\
Common stock & 100,000 & 100,000 & Inventories & 50,000 & 50,000 \\
Retained earnings & 100,000 & 100,000 & Plant and equipment & 200,000 & 200,000 \\
Total Liabilities and equity & 400,000 & 400,000 & Total Assets & 400,000 & 400,000 \\
\hline \hline
\end{tabular}




\section{REFERENCES}

Ahmed, I., Akhtar, M., Ahmed, I., \& Aziz, S. (2017). Practices of Islamic banking in the light of islamic ethics: A critical review. International Journal of Economics, Management and Accounting, 25(3), 465-490.

Akhtar, M., \& Muhammad, F. (2017). Financial sophistication, emotional quotient, and stock market participation: Theory and evidence. Journal of Islamic Business and Management, 7(1), 87-99.

Akhtar, M., Naveed, M., \& Bilal, A. R. (2016). The determinants of the cost of equity: Evidence from Pakistan. Abasyn University Journal of Social Sciences, 9(2), 527-542.

Almahrog, Y., Ali Aribi, Z., \& Arun, T. (2018). Earnings management and corporate social responsibility: UK evidence. Journal of Financial Reporting and Accounting, 16(2), 311-332.

Chandra, A., \& Wimelda, L. (2018). opportunistic behavior, external monitoring mechanisms, corporate governance, and earnings management. Accounting and Finance Review, 3(1) 44-52.

Commerford, B. P., Hatfield, R. C., \& Houston, R. W. (2018). the effect of real earnings management on auditor scrutiny of management's other financial reporting decisions. The Accounting Review.

De Marco, G., Donnini, C., Gioia, F., \& Perla, F. (2018). On the measure of contagion in fuzzy financial networks. Applied Soft Computing, 67, 584-595.

Hanif, M. (2010). Implications of earnings management for implementation of Sharia based financial system. Interdisciplinary Journal of Contemporary Research in Business.

Makarem, N., Hussainey, K., \& Zalata, A. (2018). Earnings management in the aftermath of the zero-earnings discontinuity disappearance. Journal of Applied Accounting Research, 19(3), 401-422.

Mala, R., \& Chand, P. (2015). Commentary on phase A of the revised conceptual framework: Implications for global financial reporting. Advances in Accounting, 31(2), 209-218.

Tinoco, M. H., Holmes, P., \& Wilson, N. (2018). Polytomous response financial distress models: The role of accounting, market and macroeconomic variables. International Review of Financial Analysis. 